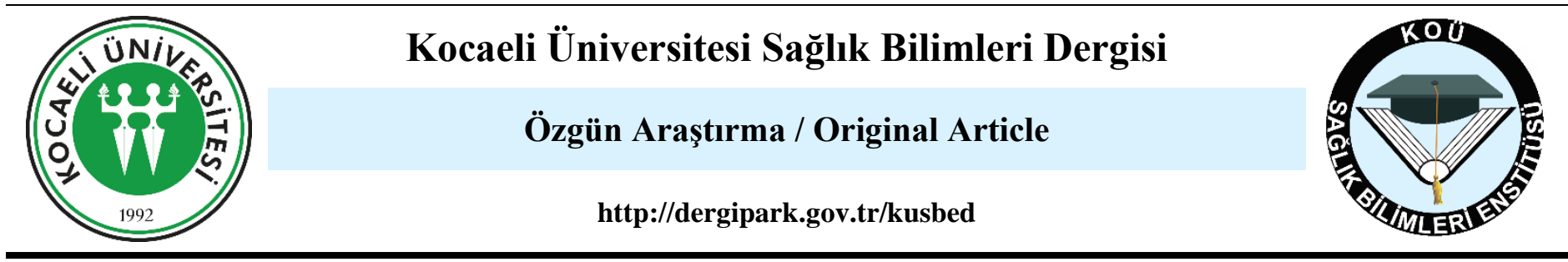

\title{
EVALUATION OF TUNNELED HEMODIALYSIS CATHETERS IN DIFFERENT VASCULAR ACCESSES
}

\section{FARKLI VASKÜLER GIRIŞ YOLLARINDA TÜNELLİ HEMODIYYALIZ KATETERLERININ DEĞERLENDIRILMESI}

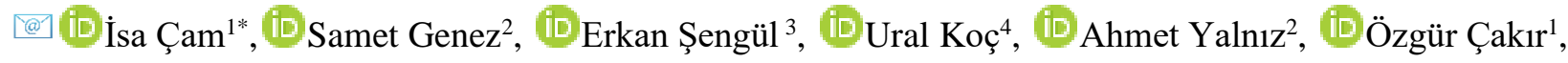 \\ Detin Ergül ${ }^{4}$, (D) Servan Yaşar $^{2}$, (D) Ceylan Altıntaş Taşlıçay ${ }^{1}$, Drcüment Çiftçi ${ }^{1}$
}

\begin{abstract}
${ }^{1}$ Kocaeli University, Faculty of Medicine, Division of Internal Medical Sciences, Department of Radiology, Kocaeli, Turkey; ${ }^{2}$ Kocaeli Derince Training And Research Hospital, ${ }^{2}$ Clinic of Radiology; ${ }^{3}$ Clinic of Nephrology, Kocaeli Turkey; ${ }^{4}$ Ankara Atatürk City Hospital, Clinic of Radiology, Ankara, Turkey; ${ }^{5}$ Kocaeli University, Faculty of Medicine, Internal Medicine, Clinic of Nephrology, Kocaeli Turkey
\end{abstract}

ORCID iD: İsa Çam: 0000-0001-9551-2364; Samet Genez: 0000-0002-1484-4496; Erkan Şengül: 0000-0003-3501-8334; Ural Koç: 0000-00028189-2885; Ahmet Yalnız: 0000-0003-3253-1554; Özgür Çakır: 0000-0001-6565-9488; Metin Ergül: 0000-0002-0706-6550; Servan Yaşar: 00000002-9404-3217; Ceylan Altıntaş Taşliçay: 0000-0003-4459-4114; Ercüment Çiftçi: 0000-0002-6536-5102

\begin{tabular}{lcc}
\hline *Sorumlu Yazar / Corresponding Author: İsa Çam & e-posta / e-mail: dr.isa.cam @ gmail.com & \\
\hline Geliş Tarihi / Received: 09.03.2021 & Kabul Tarihi / Accepted: 10.04.2021 & Yaym Tarihi / Published: 29.05.2021
\end{tabular}

\begin{abstract}
Objective: To determine the patency rates and reasons for failure using different access routes for tunneled hemodialysis catheters.

Methods: The records of patients who underwent insertion of 14 French tunnelled hemodialysis catheters were retrospectively analyzed. Catheter patency survival was demonstrated using Kaplan-Meier survival curve. Catheter failure and exchange reasons were evaluated.

Results: One hundred and six patients underwent 474 catheter exchanges (mean/patient $4.47 \pm 1.62$ ). Access was via right internal jugular vein (IJV) $n=40$, left IJV n=23, right femoral vein (FV) $n=18$, left FV $n=11$ and transhepatic vein $n=14$. The causes of catheter failure and exchange were: catheter-associated infection, catheter thrombosis, fibrin sheath and catheter tip malposition. Mean primary and cumulative catheter patency time (721 and 1276 days, respectively) was higher in the right IJV group compared with the others $(p<0.001)$. The same parameters were lowest in the transhepatic group, being 118 and 466 days, for primary and cumulative patency, respectively $(p<0.001)$. The incidence of catheter-related infections was higher in the left FV (0.42/100 patient-days) and catheter tip malposition was higher in the transhepatic $(0.38 / 100$ patient-days) and in the left IJV $(0.32 / 100$ patient-days).

Conclusion: The use of right IJV should be the first option for hemodialysis access route. Based on our findings, if right IJV is unavailable the optimal access routes in order would be left IJV, right FV, left FV and finally transhepatic vein.
\end{abstract}

Keywords: Catheter dysfunction, Catheter survival rate, Fibrin sheath, Hemodialysis, Tunneled Catheter, Vascular Access

$\ddot{O} z$

Amaç: Tünelli hemodiyaliz kateterleri için farklı vasküler erişim yollarında açıklık oranlarını ve tıkanma nedenlerini belirlemektir.

Yöntem: 14 french tünelli hemodiyaliz kateteri takılan 106 hastanın kayıtları retrospektif olarak analiz edildi (40 sağ internal jugular ven (İJV), 23 sol İJV, 18 sağ femoral ven (FV), 11 sol FV ve 14 transhepatik ven). Kateter açıklık sağkalımı Kaplan-Meier eğrisi kullanılarak gösterildi. Kateter tıkanma ve değişim nedenleri değerlendirildi.

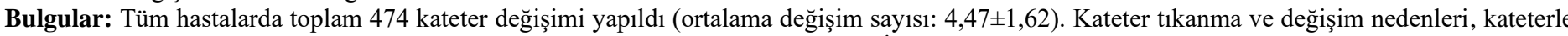
ilişkili enfeksiyon, kateter trombozu, fibrin kılıfı ve kateter malpozisyonu idi. Sağ İJV grubunda ortalama primer ve kümülatif kateter açıklık süresi diğerlerine göre daha yüksekti $(p<0,001)$. Sağ İJV grubunda ortalama kateter birincil ve kümülatif açılık süresi sırasıyla 721 ve 1276 gündü; diğer yandan transhepatik grupta en düşüktü $(p<0,001)$. Transhepatik grupta ortalama kateter birincil ve kümülatif açıklık süreleri sırasıyla 118 ve 466 gündü. Kateterle ilişkili enfeksiyonların insidansı sol FV'de (100 hasta günü için 0,42$)$ daha yüksek, kateter malpozisyonu ise transhepatik $(100$ hasta günü için 0,38$)$ ve sol İJV'de (100 hasta günü için 0,32$)$ daha yüksekti.

Sonuç: Tünelli hemodiyaliz kateteri için ilk erişim yolu sağ IJJV olmalıdır. Çalışmamızın sonuçlarına göre sağ İJV kullanılabilir değilse; sırasıyla sol İJV, sağ FV, sol FV ve transhepatik erişim yolları kullanılmalıdır.

Anahtar Kelimeler: Fibrin Kılıf, Katater disfonksiyonu, Kateter sağkalım oranı, Hemodiyaliz, Tünelli Katater, Vasküler Erişim 


\section{Introduction}

The incidence of end-stage chronic kidney disease is increasing globally and most patients are treated with hemodialysis (HD). Arteriovenous fistula (AVF) is the first option for HD access, due to long-term patency and low complication rates. ${ }^{1}$ For various reasons, including thrombosis, surgical contraindications, and maturation failure of the AVF, a tunneled hemodialysis catheter (THC) is a further option for HD access. ${ }^{2}$ A THC is suggested by the Dialysis Outcomes Quality Initiatives for patients who will need HD for longer than three weeks. ${ }^{3}$ In addition, THC is used for patients awaiting AVF or kidney transplant.

The right internal jugular vein (IJV) is recommended as the first choice for THC because of its straight line to the atrium, resulting in high patency and fewer catheter complications. ${ }^{4}$ However, this access may not be used because of various complications, such as occlusion, infection, and fibrin sheath formation of a previous catheter. When the right IJV is not available for THC placement, there are several viable choices for a second access route. It is suggested the venous access approaches for HD should be, in this order: right IJV, right external jugular vein (EJV), left IJV, left EJV, subclavian vein (SCV) if there is no possibility of later use of this site for AVF/arteriovenous graft (AVG) creation, femoral vein (FV), and finally translumbar or transhepatic inferior vena cava (IVC). ${ }^{5}$

In this retrospective study, the aim was to evaluate the patency and complication rates, and clinical follow-up of right and left IJV, right and left FV, and transhepatic access for tunneled HD catheterization.

\section{Methods}

This study was approved by the institutional review board. Records of patients undergoing THC were retrospectively reviewed from November 2016 to November 2019. Data was collected including patient demographics, comorbidities, procedure details, catheter patency times, causes of catheter failure and exchange, and catheterassociated complications.

The first preferred venous approach was the right IJV. However, if this site was unusable due to infection, thrombosis, invisible IJV on ultrasound because of variation, the left IJV was used for THC as a second option with the FV being used as the third option. A transhepatic approach was only used when all other access routes were not clinically feasible. Patients were followed until failure of vascular access or death. Patients who underwent AVF or kidney transplantation during the follow-up were excluded from the study. Translumbar catheter placement was not routinely performed before transhepatic access at our hospital because transhepatic access is associated with less risk of damage or bleeding from surrounding structures and translumbar approach is associated with fibrosis along the retroperitoneal tract, which can make revisions difficult.

SCV access was not included in this study because at our center there is a tendency not to use this access with a view to conserving access to a later possible AVF/AVG. Insertions using an EJV approach were excluded due to the small number of patients $(n=4)$. Temporary HD catheter placements were also not included in this study.

In general, $23 \mathrm{~cm}$ catheters were used for right IJV, 23 or 27 $\mathrm{cm}$ for left IJV or transhepatic approach. For the FV approach 33 or $55 \mathrm{~cm}$ catheters were used. All procedures were performed by the interventional radiologist with ultrasound and fluoroscopic guidance, under local anesthesia. Catheter placement was performed with the use of the Seldinger technique with a peel-away sheath. The catheter is locked with heparinized saline in our units. No routine antibiotic therapy was used for procedures. Prophylactic antibiotics (typically $1 \mathrm{~g}$ of cefazolin) were only used when the reason for the catheter exchange was infection. Post procedural control images were obtained to verify proper positioning. All insertions were performed by the same team of interventional radiologists.

Clinical follow-ups were carried out by nephrologists. Patients were referred to interventional radiologists in case of suspected complications associated with the catheter. Malposition was described as the catheter tip in an inappropriate vein. Standard catheter exchange practice was performed over a guide wire in case of catheter malposition (Figure 1-4). If a fibrin sheath, an occlusion consisting of fibrin around the catheter tip was observed, it was disrupted with balloon angioplasty using a $14 \mathrm{~mm}$ balloon (Figure 5). After disruption a new catheter was then advanced over the guidewire. If venous stenosis or occlusion was observed, percutaneous transluminal angioplasty (PTA) was performed with an appropriate size balloon (Figure 6).

If clinical or laboratory symptoms of possible infection were present, blood cultures were taken from the catheter and peripheral vein. Catheter-associated sepsis was defined as the presence of positive catheter-tip culture and clinical symptoms of sepsis.

A range of factors, such as age, gender, and comorbidities, were analyzed in order to assess their impact on catheter survival. The incidence of catheter failure was expressed as the number of episodes per 100 patient-days.

\section{Statistical Analysis}

The Statistical Package for Social Sciences (SPSS), version 22.0, (IBM Inc., Chicago, ILL., USA) was used for statistical analysis. Normality of distribution of the datasets was analyzed using the Kolmogorov-Smirnoff test. Variables with normal distribution were expressed as mean \pm standard deviation (SD) and non-normally distributed data as median and range. For parametric data set comparison, the Analysis of Variance (ANOVA) and Kruskal Wallis test was used for variables without non-normal distribution. Tamhane and pairwise comparisons with Bonferroni correction was used for subgroup analysis. Nominal variables were evaluated with Fisher's exact test. Catheter patency survival was assessed using Kaplan-Meier survival curves. Demographics, procedural factors and comorbidities were assessed using Cox regression analysis. A $p$ value $<0.05$ was interpreted as statistically significant.

\section{Results}

One hundred and six patients, of whom 59\% were women and with a median age 66 years (16-90), underwent catheter placements. The approaches used were right IJV $(n=40)$, left IJV $(n=23)$, right FV $(n=18)$, left FV $(n=11)$ and transhepatic $(n=14)$. Procedural success was obtained in all patients. Post-procedural images showed that the position of the catheter tip in all cases was the right atrium. There was no statistical difference $(p=0.97)$ in the number of minor complications of catheter insertion among all groups (Table $1)$.

No major complications were observed during procedures. No additional intervention was required for minor complications, except manual pressure and observation. 
There were a total of 474 exchanges in the 106 patients (mean exchange per patient $4.47 \pm 1.62$ ). The reasons for catheter exchange were catheter related infection $(113 / 474,23.83 \%)$, catheter thrombosis (132/474, $27.84 \%)$, fibrin sheath $(148 / 474,31.22 \%)$, and catheter tip malposition $(81 / 474,17.08 \%)$.

The reasons for catheter failure for each patient were: catheter related infection $(86 / 106,81.1 \%)$; catheter thrombosis (79/106, 74.5\%); fibrin sheath (76/106, $71.7 \%)$; and catheter tip malposition $(49 / 106,46.2 \%)$. The most frequent reason for catheter failure for each patient was catheter related infection in this cohort.

In the right IJV group, mean catheter primary and cumulative patency failure time were $737 \pm 232$ and $1332 \pm 283$ days, respectively. In the left IJV group, mean catheter primary and cumulative patency failure time were $259 \pm 91$ and $557 \pm 122$ days, respectively. In the right FV group, the mean catheter primary and cumulative patency failure time were $157 \pm 60$ and $405 \pm 81$ days, respectively. In the left FV group, mean catheter primary and cumulative patency failure time were $117 \pm 31$ and $407 \pm 94$ days, respectively. In the transhepatic group, mean catheter primary and cumulative patency failure time were $114 \pm 38$ and $462 \pm 82$ days, respectively. Mean primary and cumulative catheter patency was highest in the right IJV group compared with the other groups ( $p<0.001$, Figure $7-8$ and Table 2).

The highest rate of catheter exchange was found when using the left FV approach. (right IJV: 0.42 per 100 patient days; left IJV :0.71 per 100 patient-days; left FV :1.01 per 100 patient-days;, right FV :0.88 per 100 patient-days; and transhepatic :0.87 per 100 patient-days, $(p<0.001$; Figure 9).

Mean catheter related infection rate was 0.18 per 100 patient-days. The incidence of catheter-related infections per 100 patient days was highest in the left FV (right IJV 0.08 , left IJV 0.09, left FV 0.42, right FV 0.36, and transhepatic $0.17 ; p<0.001)$.

Mean catheter tip malposition rate was 0.14 per 100 patient-days. Catheter tip malposition per 100 patient days was highest in the transhepatic and next highest in the left IJV (right IJV 0.01, left IJV 0.32, left FV 0.03, right FV 0.06, and transhepatic $0.38 ; p<0.001$ )

Mean fibrin sheath rate was 0.16 per 100 patient-days. Fibrin sheath formation per 100 patient days was highest in the right IJV group (right IJV 0.21, left IJV 0.16, left FV 0.15 , right FV 0.05 , and transhepatic $0.11 ; p<0.001$ ).

Mean catheter occlusion rate was 0.12 per 100 patientdays. Catheter occlusion per 100 patient-days was highest in the right FV and then the left FV (right IJV 0.11, left IJV 0.12, left FV 0.36, right FV 0.40 , and transhepatic $0.20 ; p<0.001)$. A box plot of comparisons between the different failure rates and different approaches is shown in Figure 10. The causes of hemodialysis catheter failure were shown in Table 3.

For central vein stenosis or occlusion, 19 (17.9\%) PTA were performed and no statistical difference was found between vascular access groups $(p=0.672$; Table 1$)$.

The only positive correlation was found between gender and primary patency (Spearman's rho 0.205, $p=0.035$ ). There was no correlation between catheter failure and patient age or other comorbidities.
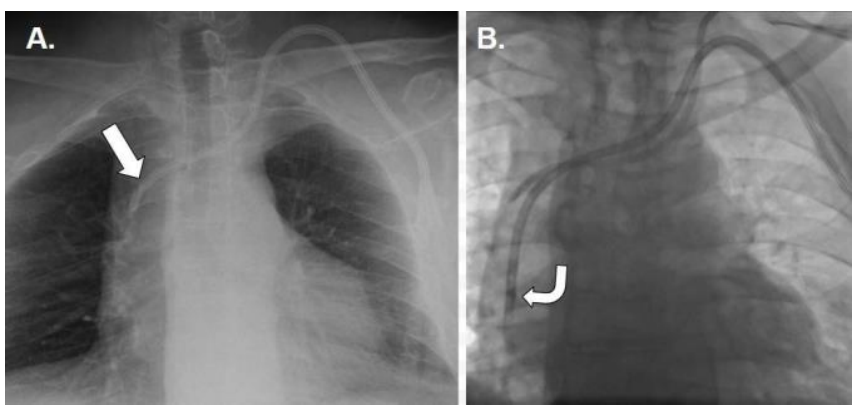

Figure 1. Malposition of left IJV THC. A. Chest radiograph obtained due to poor flow through the catheter at dialysis. The catheter tip is retracted into the junction of the upper superior vena cava and the left brachiocephalic vein (arrow). An attempt was made to reposition it through the catheter, but this was not successful due to catheter occlusion. B. A new, tunnelled catheter was inserted through the left internal jugular vein access under US guidance (curved arrow).
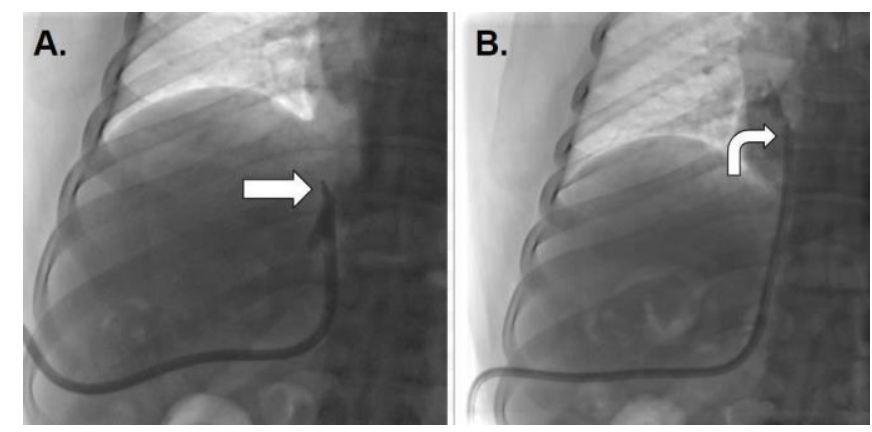

Figure 2. Malposition of transhepatic THC. A. Fluoroscopic image shows that the catheter tip is retracted into the junction of the superior vena cava and the right hepatic vein (arrow). B. Position of the catheter tip at the right atrium is seen after catheter exchange (curved arrow).
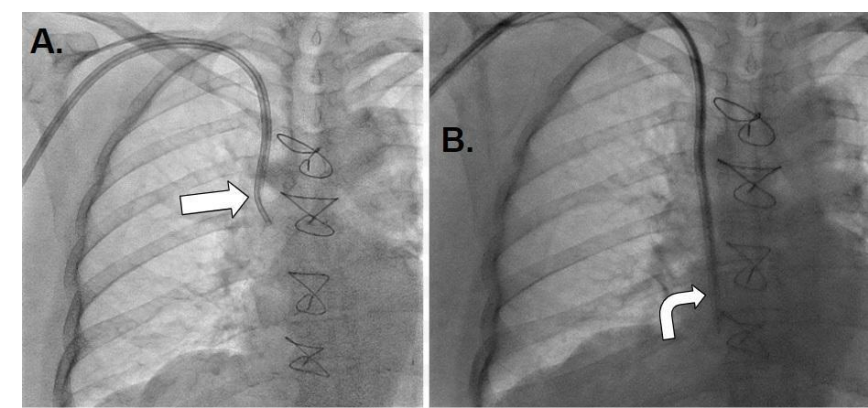

Figure 3. Malposition of right IJV. A. Fluoroscopic image demonstrates that the catheter tip is retracted into the junction of the right brachiocephalic vein (arrow). B. After exchange and reposition of the THC, the catheter tip is seen in the mid right atrium.
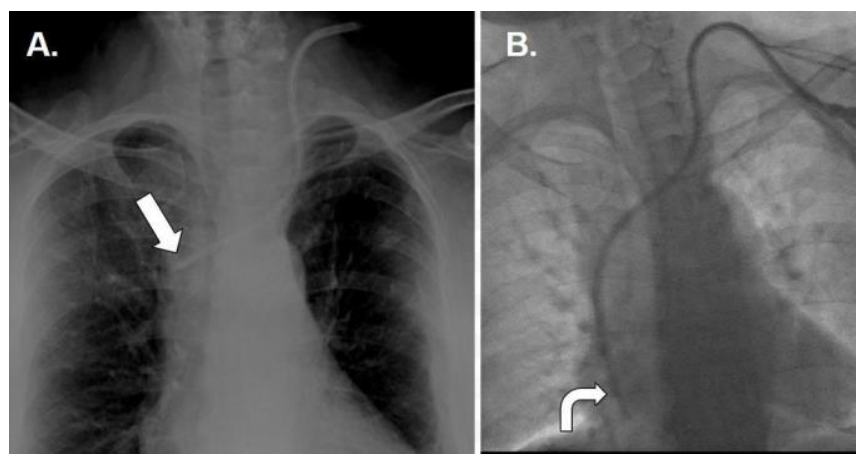

Figure 4. Malposition of left IJV THC. A. Chest radiograph demonstrates that the catheter tip is retracted into the junction of the left brachiocephalic vein (arrow). B. After exchange and reposition of the THC, the catheter tip is seen at the right atrium (curved arrow). 

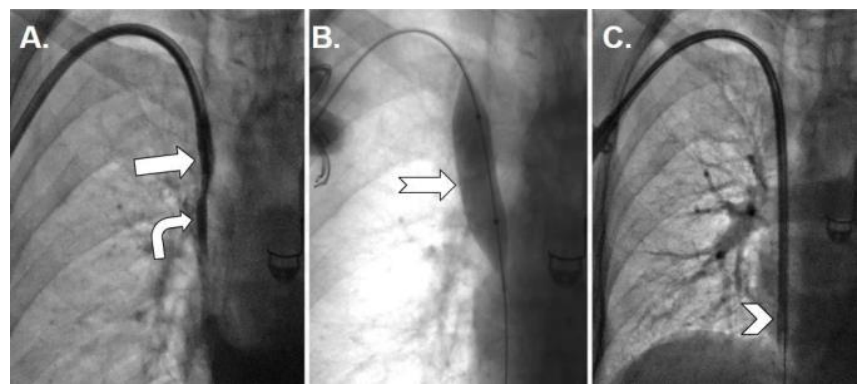

Figure 5. Images of fibrin sheath. A. Fluoroscopic image with contrast medium of the THC pulled back 5-6 cm (arrow) through the catheter demonstrating a fibrin sheath (curved arrow) B. For disruption of fibrin sheath, balloon angioplasty was performed (notched arrow). C. After disruption of fibrin sheath, a new catheter is inserted into the right atrium (arrowhead).
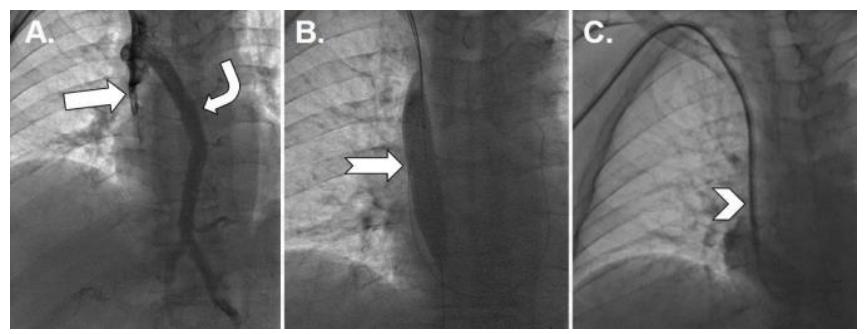

Figure 6. Occlusion of superior vena cava due to THC. A. Fluoroscopic evaluation of THC after injection of contrast medium shows occlusion of the SVC and contrast media only filling the azygos vein in retrograde fashion. B. Balloon dilation was performed, bypassing the occlusion with a hydrophilic guidewire (notched arrow). C. After recanalization SVC, a new catheter was inserted into the right atrium (arrowhead).

Table 1. Frequency and comparison of minor complications and central venous occlusion-stenosis (data are presented as $\mathrm{n}(\%)$ ).

\begin{tabular}{c|cccccc}
\hline & R IJV & L IJV & R FV & L FV & TH & $\begin{array}{c}p \\
\text { value }\end{array}$ \\
\hline $\begin{array}{c}\text { Minor } \\
\text { hemorrhage }\end{array}$ & $4(10)$ & $3(13)$ & $2(11.1)$ & $1(9)$ & $2(14.2)$ & \\
$\begin{array}{c}\text { Arterial } \\
\text { puncture }\end{array}$ & $1(2.5)$ & $1(4.3)$ & $1(5.5)$ & $1(9)$ & $1(7.1)$ & 0.968 \\
$\begin{array}{c}\text { Central venous } \\
\text { occlusion or } \\
\text { stenosis }\end{array}$ & $5(12.5)$ & $5(21.7)$ & $4(22.2)$ & $3(27.7)$ & $2(14.2)$ & 0.672 \\
\hline
\end{tabular}

Abbreviations: R IJV, right internal jugular vein; L IJV, left internal jugular vein; R $\mathrm{FV}$, right femoral vein; L FV, left femoral vein; TH, transhepatic vein.
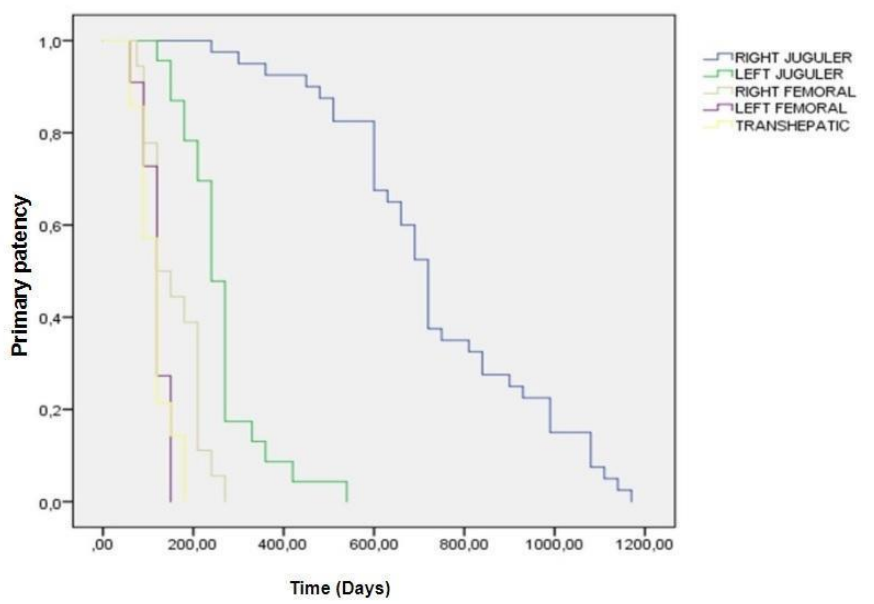

Figure 7. Primary patency by Kaplan-Meier survival analysis

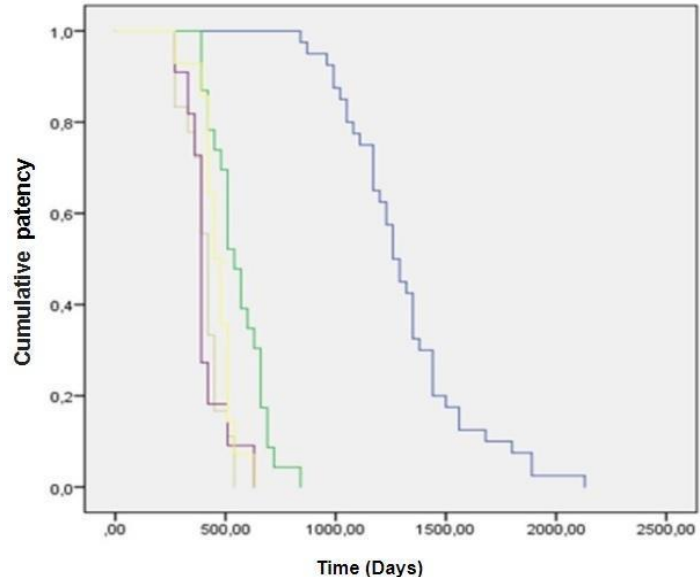

TRIGHT JUGULEP REFTT FEMORA LEFT FEMORAL

Figure 8. Cumulative patency by Kaplan-Meier survival analysis

Table 2. Primary and cumulative patency failure time of all groups

\begin{tabular}{l|lll}
\hline \multicolumn{1}{c}{} & $\begin{array}{l}\text { Primary patency } \\
\text { failure time (days) }\end{array}$ & $\begin{array}{l}\text { Cumulative patency } \\
\text { failure time(days) }\end{array}$ & $p$ \\
\hline right IJV & $737 \pm 232$ & $1332 \pm 283$ & \\
left IJV & $259 \pm 91$ & $557 \pm 122$ & $<0.001$ \\
right FV & $157 \pm 60$ & $405 \pm 81$ & \\
left FV & $117 \pm 31$ & $407 \pm 94$ & \\
TH & $114 \pm 38$ & $462 \pm 82$ & \\
\hline
\end{tabular}

Abbreviations: R IJV, right internal jugular vein; L IJV, left internal jugular vein; R $\mathrm{FV}$, right femoral vein; L FV, left femoral vein; TH, transhepatic vein.

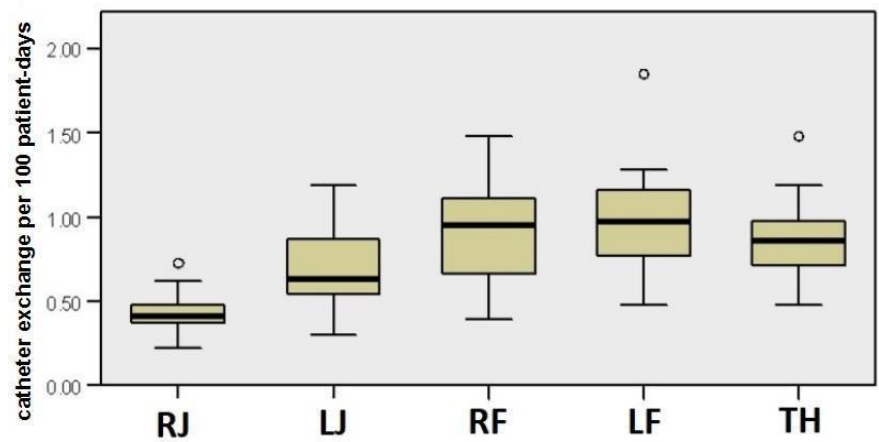

Figure 9. Box plot of vascular access route for catheter exchange versus catheter exchange per 100 patient days. RJ: right internal jugular vein, LJ: left internal jugular vein, RF: right femoral vein, LF: left femoral vein, TH: transhepatic vein.
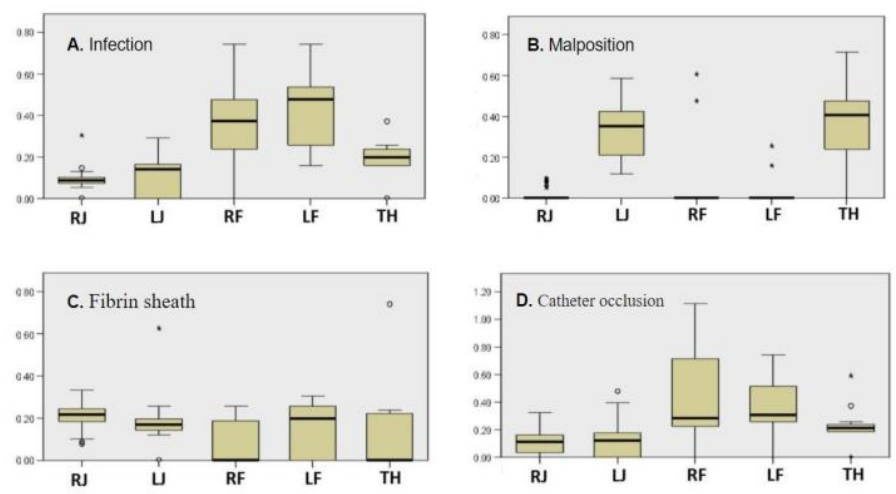

Figure 10. Box plot showing catheter failure reasons by vascular access route.RJ: right internal jugular vein, LJ: left internal jugular vein, RF: right femoral vein, LF: left femoral vein, TH: transhepatic vein. 
Table 3. Causes of hemodialysis catheter failure for all groups (per 100 patient-days)

\begin{tabular}{c|cccccc}
\hline & $\begin{array}{c}\text { right } \\
\text { IJV }\end{array}$ & $\begin{array}{c}\text { left } \\
\text { IJV }\end{array}$ & $\begin{array}{c}\text { right } \\
\text { FV }\end{array}$ & $\begin{array}{c}\text { left } \\
\text { FV }\end{array}$ & TH & $p$ value \\
\hline $\begin{array}{c}\text { Catheter } \\
\text { exchange } \\
\begin{array}{c}\text { Catheter } \\
\text { related }\end{array}\end{array}$ & 0.42 & 0.71 & 0.88 & 1.01 & 0.87 & $<0.001$ \\
$\begin{array}{c}\text { infection } \\
\text { Catheter tip }\end{array}$ & 0.08 & 0.09 & 0.36 & 0.42 & 0.17 & $<0.001$ \\
$\begin{array}{c}\text { Malposition } \\
\text { Fibrin } \\
\text { sheath }\end{array}$ & 0.21 & 0.16 & 0.05 & 0.15 & 0.11 & $<0.001$ \\
$\begin{array}{c}\text { Catheter } \\
\text { occlusion }\end{array}$ & 0.11 & 0.12 & 0.40 & 0.36 & 0.20 & $<0.001$ \\
\hline
\end{tabular}

Abbreviations: R IJV, right internal jugular vein; L IJV, left internal jugular vein; R FV, right femoral vein; L FV, left femoral vein; TH, transhepatic vein.

\section{Discussion}

It is widely accepted that AVF or grafts are the best vascular access types for HD and tunneled catheters are universally regarded as a less preferable option.6 Few studies have been conducted on the patency rates and failure reasons in different HD access routes and to the best of our knowledge, this study is one of the largest to be undertaken to date concerning THC for HD. In the present study, a comparison was performed among five types of catheterization for vascular access approach in terms of the patency and failure reasons of catheters. The results of the present study add evidence to the view that the RJV approach for THC should be the first choice. ${ }^{7-10}$

In the present study the mean catheter-related infection rate was rather low at $0.18 / 100$ catheter-days, while previously reported infection rates have varied from 0.14-0.52 episodes/100 catheter days. ${ }^{11-13}$ Nonetheless, catheter related infection, especially when FV access was used, still remained the main reason for catheter removal and were a significant risk factor for catheter failure.

Catheter malposition was observed more frequently when using the left IJV and transhepatic access, similar to previous reports. ${ }^{14,15}$ The reasons for this are that there is a long and tortuous path when placing catheters using these accesses and catheter movement during respiration, or catheter migration or dislodgement might be encountered.

The most frequent reason for catheter exchange in our cohort was fibrin sheath formation seen in $81.1 \%$ of patients needing exchange and the cause of $31.22 \%$ of all exchanges. Fibrin sheath is a common cause of late catheter failure and treatment options include exchange catheter with balloon disruption of the fibrin sheath or fibrin sheath stripping using an internal snare, or intra-catheter tissue plasminogen activator (t-PA) infusion. ${ }^{16,17}$ At our center contrast angiography was routinely performed for THC dysfunction and then an exchange catheter with balloon disruption was carried out in case of fibrin sheath formation. Shanaah et al. ${ }^{17}$ reported no effect on the site of access for THC. In the present study catheter failure because of fibrin sheath formation was most common in the right IJV group. We hypothesize that this is because other approaches may dysfunction for other reasons before fibrin sheath is formed. In this study, all procedures were performed under ultrasound guidance and were associated with a low rate of complication. Ultrasound guidance has been recommended to minimize the complication rates. ${ }^{18}$ Therefore, as interventional radiologists routinely use ultrasound and angiography suits for this type of procedure, the role of interventional radiologists in the treatment approach of dialysis patients continues to increase.

Central venous stenosis or occlusions are two of the most common complications of tunneled catheters. ${ }^{10}$ In our study 19 patients (17.9\%) with central venous stenosis or occlusion were successfully treated with PTA but no significant association was found between approach used and the occurrence of central venous stenosis or occlusion. Nevertheless, patients with THC should be monitored for stenosis and occlusion.

A positive correlation was identified between being female and primary patency. However, comorbidities, such as diabetic mellitus, heart failure, hypertension, coronary artery disease, and peripheral artery disease at the initiation of HD were not significant risk factors of THC failure. Statistical analysis may not be reliable, however, due to the small number of patients. In the literature and in contrast to our findings, diabetic mellitus and age were reported as risk factors for catheter failure. ${ }^{16,19,20}$

Our study has some limitations. First, although it has a large number of patients, the present study is a single-center, retrospective study. Second, participants were not allocated randomly to the groups. Finally, catheter lengths, types and brands were not considered when making comparisons.

\section{Conclusion}

A right IJV approach for hemodialysis catheterization should be the first option because of its high patency rate. Catheter malposition was seen more frequently when using a left IJV and transhepatic approach, while catheter related infection was seen more commonly in the FV approach group. Therefore, based on these findings, if the right IJV is unavailable the order of choice should be left IJV, right FV, left FV and finally a transhepatic approach.

\section{Acknowledgments}

The authors are grateful to Mr. Jeremy Jones of the Academic Writing Department of Kocaeli University, Izmit, Turkey, for his assistance in editing the English used and for his help and advice concerning the contents of this manuscript.

\section{Conflict of Interest}

The authors have no conflicts of interest to disclose.

\section{Financial Support}

The authors declared that no financial support was received for this paper.

\section{Author Contributions}

İÇ, EÇ: Design; İÇ, ÖÇ, CAT: Project development; İÇ, ÖÇ, ME, CAT: Data collection; İÇ, SG, EŞ, UK, SY: Analysis; İÇ, ÖÇ, ME, CAT, EŞ: Literature search; İÇ, SG, EŞ, AY, EŞ Manuscript writing; İÇ, SG, EŞ, AY, SY,CAT, EÇ: Critical review

\section{References}

1. Vascular Access Work Group. Clinical practice guidelines for vascular access. Am J Kidney Dis. 2006;48(suppl1):248-273.

2. Saran R, Li Y, Robinson B, et al: US Renal Data System 2015 Annual Data Report: Epidemiology of kidney disease in the United States. Am J Kidney Dis. 2016;67: 1-305.

3. III. NKF-K/DOQI Clinical Practice Guidelines for Vascular Access: update 2000. Am J Kidney Dis. 2001;37: 137-181. 
4. Kukita K, Ohira S, Amano I, et al. 2011 update Japanese Society for Dialysis Therapy guidelines of vascular access construction and repair for chronic hemodialysis. Ther Apher Dial. 2015;19:1-39.

5. Rakesh N, Sidney R. The KDOQI 2006 vascular access update and fistula first program synopsis. Semin Intervent Radiol. 2009;26(2):122-124.

6. Polkinghorne KR, Chin GK, MacGinley RJ, et al. KHA-CARI Guideline: Vascular Access- central venous catheters, arteriovenous fistulae and arteriovenous grafts. Nephrology (Carlton). 2013;18(11):701-705.

7. Maya ID, Allon M. Outcomes of tunneled femoral hemodialysis catheters: Comparison with internal jugular vein catheters. Kidney Int. 2005;68(6):2886-2889.

8. Schillinger F, Schillinger D, Montagnac R, Milcent T. Post catheterisation vein stenosis in haemodialysis: Comparative angiographic study of 50 subclavian and 50 internal jugular accesses. Nephrol Dial Transplant. 1991;6(10):722-724.

9. Guillermo-Corpus G, Ramos-Gordillo JM, Peña-Rodríguez JC. Survival and Clinical Outcomes of Tunneled Central Jugular and Femoral Catheters in Prevalent Hemodialysis Patients. Blood Purif. 2019;47(1-3):132-139.

10. Pereira K, Osiason A, Salsamendi J. Vascular Access for Placement of Tunneled Dialysis Catheters for Hemodialysis: A Systematic Approach and Clinical Practice Algorithm. $J$ Clin Imaging Sci. 2015; 29:31.

11. Ervo S, Cavatorta F, Zollo A. Implantation of permanent jugular catheters in patients on regular dialysis treatment: ten years' experience. J Vasc Access. 2001;2(2):68-72.

12. Ewing F, Patel D, Petherick A, Winney R, McBride K. Radiological placement of the AshSplit hemodialysis catheter: a prospective analysis of outcome and complications. Nephrol Dial Transplant. 2002;17(4):614-619.

13. Weber E, Liberek T, Wołyniec W, Gruszecki M, Rutkowski B. Survival of tunneled hemodialysis catheters after percutaneous placement. Acta Biochim Pol. 2016;63(1):139143.

14. Coker MA, Black JR, Li Y, et al. An analysis of potential predictors of tunneled hemodialysis catheter infection or dysfunction. $J$ Vasc Access. 2019;20(4):380-385.

15. Şanal B, Nas ÖF, Doğan N, et al. Safety and functionality of transhepatic hemodialysis catheters in chronic hemodialysis patients. Diagn Interv Radiol. 2016;22(6):560-565.

16. Valliant AM, Chaudhry MK, Yevzlin AS, Astor B, Chan MR. Tunneled dialysis catheter exchange with fibrin sheath disruption is not associated with increased rate of bacteremia. $J$ Vasc Access. 2015;16(1):52-56.

17. Shanaah A, Brier M, Dwyer A. Fibrin sheath and its relation to subsequent events after tunneled dialysis catheter exchange. Semin Dial. 2013;26(6):733-737.

18. National Institute for Clinical Excellence. Guidance on the use of ultrasound locating devices for placing central venous catheters. London: NICE, 2002.

19. Shi M, Cui T, Ma L, Zhou L, Fu P. Catheter Failure and Mortality in Hemodialysis Patients with Tunneled Cuffed Venous Catheters in a Single Center. Blood Purif. 2017;43(4):321-326.

20. Fry AC, Stratton J, Farrington K, et al. Factors affecting longterm survival of tunnelled haemodialysis catheters-a prospective audit of 812 tunnelled catheters. Nephrol Dial Transplant. 2008;23(1):275-81. 